\title{
Influence of mineral fertilizers, seed treatment and herbicide on the yield of spring wheat in the conditions of the Republic of Tatarstan
}

\author{
Marat Amirov ${ }^{1}$, Igor Serzhanov ${ }^{1, *}$, Farit Shaikhutdinov ${ }^{1}$, Albina Serzhanova ${ }^{1}$, and Kurbonali Partoev ${ }^{2}$ \\ ${ }^{1}$ Kazan State Agrarian University, 420015, Kazan, Republic of Tatarstan, Russia \\ ${ }^{2}$ Laboratory of genetics and plant breeding, Institute of Botany, Physiology and Plant Genetics, Academy of Sciences of the Republic of \\ Tajikistan, Dushanbe, Tajikistan
}

\begin{abstract}
The paper presents the results of studies on the creation of an optimal nutritional regime with an analysis of weediness of crops with increased pre-sowing treatment of seeds of growth processes and the resistance of the plants themselves under stressful conditions to form a spring wheat crop. In the initial period of spring wheat vegetation, when plants are affected by sharp temperature fluctuations, soil and atmospheric droughts, it is important to stimulate their stable development and resistance to stress. When satisfying the needs of crops for nutrients, it is important to prevent weeding of crops. The purpose of our study is to study the complex effect of mineral fertilizers, the use of a herbicide and presowing seed treatment with a growth regulator on spring wheat productivity. The studies were conducted in 2016-2018 on the basis of Kazan State Agrarian University on gray forest soil. An analysis of the development of plants on weed grown variants revealed a decrease in the safety of seedlings for harvesting, decreased yield by $0.15-0.28 \mathrm{t} / \mathrm{ha}$ and reduced grain quality. The average yield of spring wheat over the years of research when using the herbicide against the background without fertilizers was $1.53 \mathrm{t} / \mathrm{ha}$, $2.66 \mathrm{t} / \mathrm{ha}$ against the background of NPK to obtain $3 \mathrm{t} / \mathrm{ha}$ of grain and $3.22 \mathrm{t} / \mathrm{ha}$ against the background of NPK to obtain $4 \mathrm{t} / \mathrm{ha}$ of grain. Combined seed treatment with the growth regulator Zircon and dressing agents contributed to an increase in yield in all nutritional backgrounds by another $3.2-4.4 \%$ and an increase in the grain nature and gluten content in fertilized nutritional backgrounds.
\end{abstract}

\section{Introduction}

Increasing the yield and quality of spring wheat grain remains one of the most important tasks of Tatarstan farmers. To solve this problem, at the very beginning of the growing season, it is necessary to form aligned, friendly seedlings on the field [1-3]. Spring wheat from this phase, when its root system is poorly developed, suffers from insufficient food and moisture in the soil, and weakly competes with weeds. In recent decades, due to an increase in the number of subsurface and minimal tillage, the use of direct sowing, and violations of the optimal timing of technological methods, the weediness of the fields has increased.

The herbicide correctly selected according to the phytosanitary state of the field and compliance with the regulations for its use makes it possible to combat weeds $[4,5]$. For the active life of plants, nutrients are needed. Increasing the content of nutrients in the soil allows plants to increase productivity and indicators of product quality $[6,7]$.
According to many researchers, one of the ways to increase crop productivity is the use of growth regulators used for seed treatment $[8,9]$. Zircon is a new generation of biologically active drugs, the active ingredient of which is a mixture of hydroxycinnamic acids isolated from purple coneflower. The purpose of our study is to study the complex effect of mineral fertilizers, the use of a herbicide and presowing seed treatment with a growth regulator on spring wheat productivity.

\section{Methods of Research}

The studies were carried out in 2016-2018 on the basis of Kazan State Agrarian University on gray forest soil. The agrochemical state of the soil was as follows: easily hydrolyzable nitrogen (according to Kornfield) amounted to $105-122 \mathrm{mg} / \mathrm{kg}$; mobile phosphorus and exchange potassium (according to Kirsanov) was 204-208 and $91-98 \mathrm{mg} / \mathrm{kg}$ of soil, respectively; the $\mathrm{pH}$ of the salt extract was 5.5 .

\footnotetext{
*Corresponding author: igor.serzhanov@mail.ru
} 
The field experiment scheme included the study of the following variants:

Nutritional background (factor A) - without fertilizers (control); calculation of fertilizers by the balance method $\left(\mathrm{N}_{61} \mathrm{P}_{55} \mathrm{~K}_{55}\right)$ for grain productivity of $3 \mathrm{t} / \mathrm{ha}$; Calculation of fertilizers by the balance method $\left(\mathrm{N}_{120} \mathrm{P}_{126} \mathrm{~K}_{97}\right)$ for a grain yield of $4 \mathrm{t} / \mathrm{ha}$.

Seed treatment (factor B) - without treatment (control); Zircon (growth regulator) $(1.21 / \mathrm{t}$ ); Dospekh 3 (fungicide) $(1.5 \mathrm{l} / \mathrm{t})$; Zircon $(1.2 \mathrm{l} / \mathrm{t})+$ Dospekh $3(1.5 \mathrm{l} / \mathrm{t})$.

Use of the herbicide - without treatment (control); treatment of crops with a herbicide (Prima 0.5 1/ha + Grand Star $15 \mathrm{~g} / \mathrm{ha}$ ) in the tillering phase of spring wheat. The experiments were laid in triplicate, plots were placed sequentially. Plot area: $35 \mathrm{~m} \times 1.65 \mathrm{~m}=58 \mathrm{~m}^{2}$, half of which was treated with a herbicide. The accounting area for cleaning was $25 \mathrm{~m}^{2}$.
The predecessor was winter rye. The object of the study was spring soft wheat of the Yoldiz variety. The mathematical processing of the research data was carried out according to B.A. Dospekhov using programs for Microsoft Excel [10].

\section{Results and Discussion}

During the years of research, the onset of spring, temperature conditions, and the periods of heating of the upper soil layer were different. The number of weeds at the time of harvesting varied depending on the used agricultural practices and weather conditions (Fig. 1). For 2016-2018, the greatest weed growth was $31-33 \mathrm{pcs} / \mathrm{m}^{2}$ against the background without treatment with herbicide without fertilizers and $26-30 \mathrm{pcs} / \mathrm{m}^{2}$ on fertilized backgrounds.

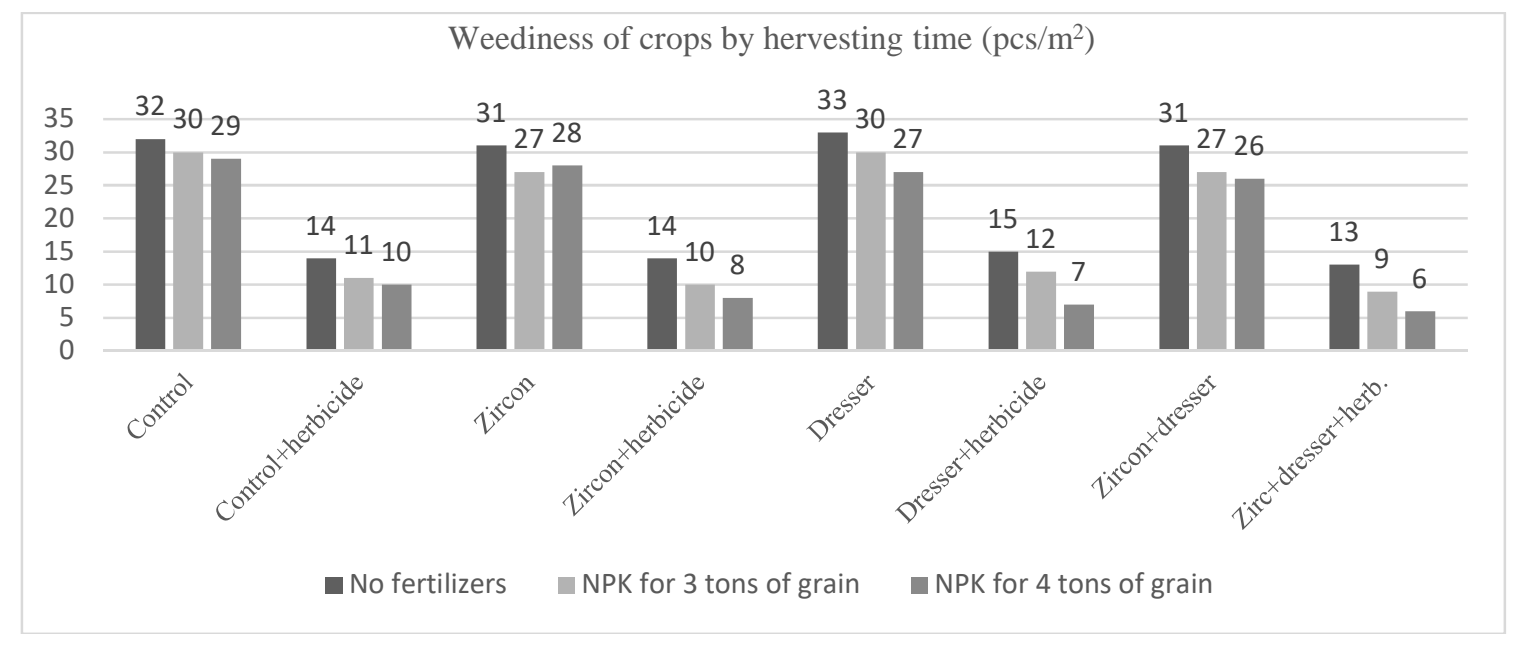

Fig. 1 Effect of herbicide treatment, fertilizers and a growth regulator on the weediness of spring wheat crops by the time of harvesting, 2016-2018

A tangible result in reducing weediness is manifested in agricultural activities not according to calendar dates, but according to the phases of plant development, the orientation of technological systems to the formation of strictly defined parameters of sowing productivity elements. In spring wheat, after tillering, the period between the phase of the second node and the appearance of the flag leaf is a large critical period, when the sensitivity of plants to a deficiency of nutrients, water, and light sharply increases.

The combination of pre-sowing seed treatment with the Zircon growth regulator together with a dressing agent and with the introduction of calculated doses of mineral fertilizers ensured the formation of sufficiently developed wheat plants, depriving the living space of weeds, the number of which decreased from 29-30 to $26-27 \mathrm{pcs} / \mathrm{m}^{2}$.

The smallest weed growth was observed when the crops were treated with a herbicide during the tillering phase of spring wheat: from 13 to $15 \mathrm{pcs} / \mathrm{m}^{2}$ against the background without fertilizers, from 9 to $12 \mathrm{pcs} / \mathrm{m}^{2}$ against the background of NPK for 3 tons of grain and from 6 to 10 $\mathrm{pcs} / \mathrm{m}^{2}$ for NPK background for $4 \mathrm{t}$ of grain. Against the background of the use of the herbicide, the use of the Zircon growth regulator together with the treating agent reduced the weediness of spring wheat on fertilized backgrounds to 6-9 $\mathrm{pcs} / \mathrm{m}^{2}$.

In spring wheat crops, there is a direct correlation between the presence of weeds during the critical period of their development, from the phase of emergence into the tube to heading, and the safety of seedlings to harvesting, the greater the weediness, the lower the safety of plants. The use of calculated doses of fertilizers in comparison with the control contributed to the preservation of spring wheat plants before harvesting without using a herbicide from 74 to $84-86 \%$, when using a herbicide from 78 to $85-87 \%$ (Fig. 2).

Presowing seed treatment with Zircon growth stimulator is important because it affects the growth rate of spring wheat plants in the initial stage of organogenesis. Also, the 
advisability of presowing treatment with a treating agent is that the effect of fungicide on the protection of young plants from disease damage increases and their preservation is increased.
Pre-sowing seed treatment with Zircon growth stimulant together with the treating agent increased the preservation of plants in comparison with the control for all food backgrounds without herbicide by another $2 \%$ and by $3-4 \%$ when using the herbicide.

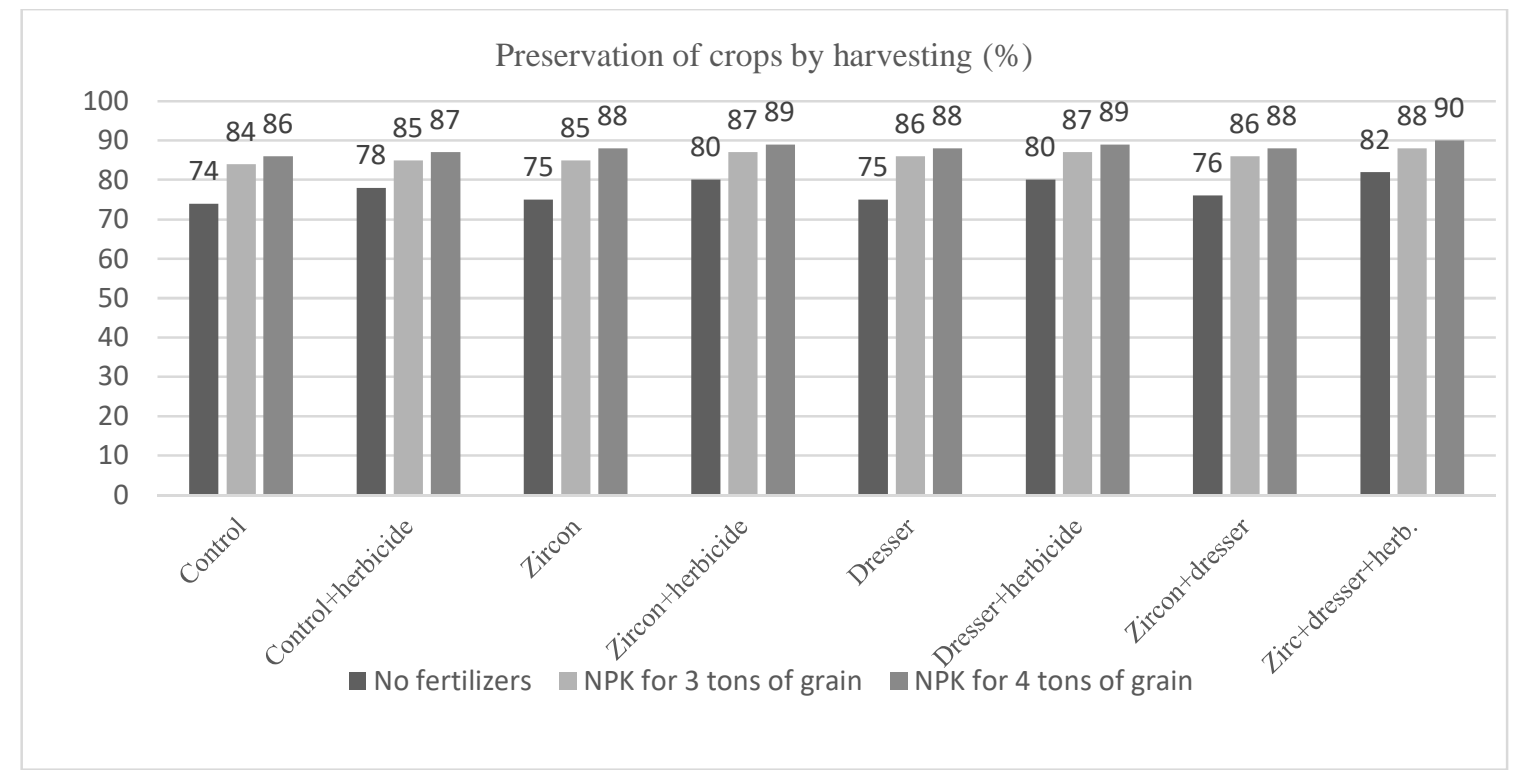

Fig. 2 Treatment on crops with herbicide, seed treatment and the use of fertilizer on the safety of seedlings for harvesting spring wheat, 2016-2018

The average yield of spring wheat for 2016-2018 without the use of the herbicide against the background without fertilizers and without seed treatment amounted to
$1.38 \mathrm{t} / \mathrm{ha}, 2.44 \mathrm{t} / \mathrm{ha}$ on the plot $\mathrm{N}_{61} \mathrm{P}_{55} \mathrm{~K}_{55}$-fertilized for 3 tons of grain and $2.94 \mathrm{t} /$ ha on the plot $\mathrm{N}_{120} \mathrm{P}_{126} \mathrm{~K}_{97}$-fertilized for 4 tons of grain (Table 1).

Table 1. The yield of spring wheat ( $\mathrm{t} / \mathrm{ha}$ ) when using mineral fertilizers, presowing seed treatment, and without herbicide 2016-2018

\begin{tabular}{|c|c|c|c|c|c|}
\hline \multirow[t]{2}{*}{ Year } & \multirow{2}{*}{$\begin{array}{l}\text { Nutritional } \\
\text { background }\end{array}$} & \multicolumn{4}{|c|}{ Presowing seed treatment (factor B) } \\
\hline & & Control & Zircon & Dresser & Zircon+dresser \\
\hline \multirow{5}{*}{2016} & No fertilizer & 1.35 & 1.44 & 1.42 & 1.46 \\
\hline & NPK for $3 \mathrm{t} / \mathrm{ha}$ & 1.91 & 2.06 & 2.05 & 2.14 \\
\hline & NPK for $3 \mathrm{t} / \mathrm{ha}$ & 2.17 & 2.33 & 2.32 & 2.43 \\
\hline & Average & 1.81 & 1.94 & 1.93 & 2.01 \\
\hline & $\mathrm{LSD}_{05}$ for & \multicolumn{4}{|c|}{$(\mathrm{A})=0.13 ;(\mathrm{B}, \mathrm{AB})=0.05 ;($ partial average $)=0.05$} \\
\hline \multirow{5}{*}{2017} & No fertilizer & 1.52 & 1.69 & 1.65 & 1.73 \\
\hline & NPK for $3 \mathrm{t} / \mathrm{ha}$ & 2.96 & 3.19 & 3.16 & 3.28 \\
\hline & NPK for $3 \mathrm{t} / \mathrm{ha}$ & 3.93 & 4.16 & 4.15 & 4.32 \\
\hline & Average & 2.80 & 3.01 & 2.99 & 3.11 \\
\hline & $\mathrm{LSD}_{05}$ for & \multicolumn{4}{|c|}{$(\mathrm{A})=0.35 ;(\mathrm{B}, \mathrm{AB})=0.12 ;($ partial average $)=0.14$} \\
\hline \multirow{5}{*}{2018} & No fertilizer & 1.27 & 1.42 & 1.35 & 1.48 \\
\hline & NPK for $3 \mathrm{t} / \mathrm{ha}$ & 2.46 & 2.69 & 2.65 & 2.76 \\
\hline & NPK for $3 \mathrm{t} / \mathrm{ha}$ & 2.73 & 2.96 & 2.93 & 3.12 \\
\hline & Average & 2.15 & 2.36 & 2.31 & 2.45 \\
\hline & $\mathrm{LSD}_{05}$ for & \multicolumn{4}{|c|}{$(\mathrm{A})=0.25 ;(\mathrm{B}, \mathrm{AB})=0.08 ;($ partial average $)=0.10$} \\
\hline \multirow{3}{*}{$\begin{array}{c}\text { Over } \\
2016- \\
2018 \\
\end{array}$} & No fertilizer & 1.38 & 1.52 & 1.47 & 1.56 \\
\hline & NPK for $3 \mathrm{t} / \mathrm{ha}$ & 2.44 & 2.65 & 2.62 & 2.73 \\
\hline & NPK for $3 \mathrm{t} / \mathrm{ha}$ & 2.94 & 3.15 & 3.13 & 3.29 \\
\hline
\end{tabular}


Table 2. Yield of spring wheat (t/ha) when using mineral fertilizers, presowing treatment of seeds and herbicide, 2016-2018

\begin{tabular}{|c|c|c|c|c|c|}
\hline \multirow[t]{2}{*}{ Year } & \multirow[t]{2}{*}{ Nutritional background } & \multicolumn{4}{|c|}{ Presowing seed treatment (factor B) } \\
\hline & & Control & Zircon & Dresser & Zircon+dresser \\
\hline \multirow{5}{*}{2016} & No fertilizer & 1.43 & 1.52 & 1.50 & 1.56 \\
\hline & NPK for $3 \mathrm{t} / \mathrm{ha}$ & 2.07 & 2.21 & 2.20 & 2.26 \\
\hline & NPK for $3 \mathrm{t} / \mathrm{ha}$ & 2.43 & 2.60 & 2.60 & 2.70 \\
\hline & Average & 1.98 & 2.11 & 2.10 & 2.17 \\
\hline & $\mathrm{LSD}_{05}$ for & \multicolumn{4}{|c|}{$(\mathrm{A})=0.15 ;(\mathrm{B}, \mathrm{AB})=0.05 ;($ partial average $)=0.06$} \\
\hline \multirow{5}{*}{2017} & No fertilizer & 1.71 & 1.88 & 1.85 & 1.96 \\
\hline & NPK for $3 \mathrm{t} / \mathrm{ha}$ & 3.23 & 3.45 & 3.42 & 3.56 \\
\hline & NPK for $3 \mathrm{t} / \mathrm{ha}$ & 4.22 & 4.44 & 4.43 & 4.61 \\
\hline & Average & 3.05 & 3.26 & 3.23 & 3.38 \\
\hline & $\mathrm{LSD}_{05}$ for & \multicolumn{4}{|c|}{$(\mathrm{A})=0.39 ;(\mathrm{B}, \mathrm{AB})=0.13 ;($ partial average $)=0.16$} \\
\hline \multirow{5}{*}{2018} & No fertilizer & 1.44 & 1.60 & 1.56 & 1.70 \\
\hline & NPK for $3 \mathrm{t} / \mathrm{ha}$ & 2.68 & 2.90 & 2.85 & 3.01 \\
\hline & NPK for $3 \mathrm{t} / \mathrm{ha}$ & 3.02 & 3.23 & 3.21 & 3.40 \\
\hline & Average & 2.38 & 2.58 & 2.54 & 2.70 \\
\hline & LSD05 for & \multicolumn{4}{|c|}{$(\mathrm{A})=0.23 ;(\mathrm{B}, \mathrm{AB})=0.09 ;($ partial average $)=0.09$} \\
\hline \multirow{3}{*}{$\begin{array}{c}\text { Over } \\
2016- \\
2018\end{array}$} & No fertilizer & 1.53 & 1.67 & 1.64 & 1.74 \\
\hline & NPK for $3 \mathrm{t} / \mathrm{ha}$ & 2.66 & 2.85 & 2.82 & 2.94 \\
\hline & NPK for $3 \mathrm{t} / \mathrm{ha}$ & 3.22 & 3.42 & 3.41 & 3.57 \\
\hline
\end{tabular}

Pre-sowing seed treatment with the Zircon growth regulator on the background without fertilizer and without the use of herbicide allowed to form a yield of $1.52 \mathrm{t} / \mathrm{ha}$, on fertilized NPK for 3 tons of grain - 2.65, on fertilized NPK for 4 tons of grain $-3.15 \mathrm{t} / \mathrm{ha}$. The increase in the yield from the use of the fungicide on all nutritional backgrounds compared to control ranged from 0.09 to $0.19 \mathrm{t} / \mathrm{ha}$.

The highest yields where no herbicide was used were obtained during joint presowing treatment of seeds with a growth stimulant and dressing agent against the background without fertilizers $1.56 \mathrm{t} / \mathrm{ha}, 2.73 \mathrm{t} / \mathrm{ha}$ on the plot NPK-fertilized for 3 tons of grain, and 3.29 t/ha on the plot NPL-fertilized for 4 tons of grain.

The average yield over the years of research when using the herbicide without seed treatment according to the corresponding nutritional background was 1.53, 2.66 and $3.22 \mathrm{t} / \mathrm{ha}$, that is, $0.15-0.28 \mathrm{t} / \mathrm{ha}$ more compared to the weed-grown areas of the same backgrounds (Table 2). The treatment of spring wheat seeds before sowing with Zircon enhanced the formation of the root system, leaf surface, and resistance to stress at the very beginning of the growing season, which subsequently increased the yield on a fertilizer-free background to $1.67 \mathrm{t} / \mathrm{ha}$ and to 2.85 and $3.42 \mathrm{t} / \mathrm{ha}$ on fertilized ones.

Comprehensive seed treatment with the Zircon growth regulator and dressing agent when spraying with the herbicide during the tillering phase of spring wheat contributed to the formation of maximum yields for each nutrition background, respectively 1.74, 2.94 and $3.57 \mathrm{t} / \mathrm{ha}$. At the same time, it can be said that against the background of $\mathrm{N}_{61} \mathrm{P}_{55} \mathrm{~K}_{55}$ fertilizer, a significant proportion of the increase in yield is accounted for by the use of mineral fertilizers $(1.13 \mathrm{t} / \mathrm{ha})$; a smaller share is due to the presowing treatment of seeds. The conversion efficiency of one $\mathrm{kg}$ of active agent in the applied mineral fertilizer in the background with the addition of $171 \mathrm{~kg}$ of active agent per ha in the control amounted to $6.61 \mathrm{~kg}$ of grain. When using the Zircon growth regulator and dressing agent, it increased to $7.02 \mathrm{~kg}$. With an increase in the dose of applied fertilizers to $\mathrm{N}_{120} \mathrm{P}_{126} \mathrm{~K}_{97}$, a maximum yield increase of $1.69 \mathrm{t} / \mathrm{ha}$ was achieved in the control and another $0.14 \mathrm{t} / \mathrm{ha}$ from the joint treatment of seeds with a growth regulator and dressing agent. In this case, the conversion efficiency of one $\mathrm{kg}$ of active agent in the mineral fertilizer decreased and in the control variant it amounted to only $4.93 \mathrm{~kg}$ of grain. With presowing treatment with Zircon and dressing agent it amounted to $5.33 \mathrm{~kg}$.

Changes in the quality of spring wheat grain over the years of research occurred mainly due to the use of calculated doses of NPK. Against the background without fertilizers, with and without the herbicide, the mass fraction of gluten in the grain of spring wheat is low and the quality of the grain corresponded only to product class IV (Table 3 ). Productivity and grain quality largely depend on soil fertility, plant supply with nutrients. Against the background of estimated NPK doses for receiving $3 \mathrm{t} / \mathrm{ha}$ of grain, the indicators of nature increased by $5-13 \mathrm{~g}$, the mass fraction of gluten raised by $4.8-5.8 \%$ compared with the background without fertilizers. Pre-sowing seed treatment with the Zircon growth regulator contributed to an increase in the gluten mass fraction up to $28 \%$, and its quality corresponded to group I, and the grain quality to the requirements of product class II. This is the confirmation that in spring wheat plants nitrogenous substances enter the weevil both due to the synthetic processes of actively functioning plant organs, and due to the recycling of previously accumulated substances in vegetative organs. Against the background of NPK for receiving $4 \mathrm{t} / \mathrm{ha}$ of grain in all variants, the quality of the obtained grain corresponded to the requirements of class II goods. 
Table 3. Grain quality of spring wheat depending on use of fertilizers, herbicide and seed treatment, 2016-2018

\begin{tabular}{|c|c|c|c|c|c|c|}
\hline \multirow[t]{2}{*}{ Crop treatment } & \multirow[t]{2}{*}{ Seed treatment } & \multicolumn{4}{|c|}{ Grain Quality Indicators } & \multirow[t]{2}{*}{ Product class } \\
\hline & & Nature $[\mathrm{g} / \mathrm{l}]$ & $\begin{array}{l}\text { Gluten mass } \\
\text { fraction [\%] }\end{array}$ & $\begin{array}{l}\text { FDM } \\
\text { [score] }\end{array}$ & $\begin{array}{c}\text { Vitreousness } \\
{[\%]}\end{array}$ & \\
\hline \multicolumn{7}{|c|}{ No fertilizers } \\
\hline \multirow{4}{*}{ No herbicide } & 1.Control & 729 & 19.8 & 98 (II gr.) & 70 & IV \\
\hline & 2.Zircon & 748 & 21.0 & 86 (II gr.) & 68 & IV \\
\hline & 3.Dresser & 740 & 22.3 & 84 (II gr.) & 70 & IV \\
\hline & 4.Zircon+dresser & 744 & 20.2 & 94 (II gr.) & 68 & IV \\
\hline \multirow{4}{*}{ With herbicide } & 1.Control & 731 & 20.7 & 96 (II gr.) & 70 & IV \\
\hline & 2.Zircon & 748 & 21.1 & 86 (II gr.) & 68 & IV \\
\hline & 3.Dresser & 742 & 21.6 & 84 (II gr.) & 70 & IV \\
\hline & 4.Zircon+dresser & 745 & 20.5 & 92 (II gr.) & 67 & IV \\
\hline \multicolumn{7}{|c|}{ NPK for $3 t / h a$} \\
\hline \multirow{4}{*}{ No herbicide } & 1.Control & 742 & 24.6 & 82 (II gr.) & 73 & III \\
\hline & 2.Zircon & 750 & 28.0 & 72 (I gr.) & 74 & II \\
\hline & 3.Dresser & 752 & 27.4 & 80 (II gr.) & 76 & III \\
\hline & 4.Zircon+dresser & 751 & 25.9 & 80 (II gr.) & 73 & III \\
\hline \multirow{4}{*}{ With herbicide } & 1.Control & 743 & 24.3 & 82 (II gr.) & 73 & III \\
\hline & 2.Zircon & 753 & 28.1 & 70 (I gr.) & 74 & II \\
\hline & 3.Dresser & 753 & 27.7 & 80 (II gr.) & 76 & III \\
\hline & 4.Zircon+dresser & 752 & 26.1 & 80 (II gr.) & 74 & III \\
\hline \multicolumn{7}{|c|}{ NPK for $4 \mathrm{t} / \mathrm{ha}$} \\
\hline \multirow{4}{*}{ No herbicide } & 1.Control & 743 & 28.0 & 72 (I gr.) & 74 & II \\
\hline & 2.Zircon & 754 & 30.0 & 66 (I gr.) & 72 & II \\
\hline & 3.Dresser & 753 & 28.3 & 68 (I gr.) & 73 & II \\
\hline & 4.Zircon+dresser & 750 & 29.2 & 68 (I gr.) & 74 & II \\
\hline \multirow{4}{*}{ With herbicide } & 1.Control & 744 & 28.1 & 70 (I gr.) & 74 & II \\
\hline & 2.Zircon & 755 & 30.1 & 64 (I gr.) & 73 & II \\
\hline & 3.Dresser & 755 & 28.4 & 68 (I gr.) & 73 & II \\
\hline & 4.Zircon+dresser & 753 & 29.5 & 66 (I gr.) & 74 & II \\
\hline
\end{tabular}

\section{Conclusion}

The use of $\mathrm{N}_{61} \mathrm{P}_{55} \mathrm{~K}_{55}$ and $\mathrm{N}_{120} \mathrm{P}_{126} \mathrm{~K}_{97}$ mineral fertilizers, a herbicide in the tillering phase of spring wheat, seed treatment with a growth regulator Zircon together with a seed dresser reduced the number of weeds, increased the preservation of shoots for harvesting, yield and grain quality indicators of spring wheat.

\section{References}

1. M. Amirov, F. Shaykhutdinov, I. Serzhanov, N. Semushkin, Journal of Fundamental and Applied Sciences, 9(1S), 559-568 (2017)

2. M.R. Akhmetzyanov, I.P. Talanov, L.T. Vafina, Bulletin of Kazan Agrarian University, 1(39), 5-9 (2016)

3. V.A. Isaychev, N.N. Andreev, V.G. Polovinkin, S.V. Antonova, Research Journal of Pharmaceutical, Biological and Chemical Sciences, 8(2), 1974-1983 (2017)
4. F.Sh. Shaikhutdinov, I.M. Serzhanov, M.F. Amirov, A.R. Valiev, R.M. Nizamov, IOP Conf. Series: Earth and Environmental Science, 341, 012091 doi:10.1088/1755-1315/341/1/012091 (2019).

5. V.I. Kostin, F.A. Mudarisov, A.I. Krivova, Bulletin of the Russian Academy of Natural Sciences, 6, 54-57 (2014)

6. T.L. Kurnosova, L.V. Osipova, I.V. Vernichenko, et al., Problems of agrochemistry and agroecology, 3, 13-23 (2017)

7. A.M. Lentochkin, Biological needs - the basis of spring wheat cultivation technology: monograph (Izhevsk State Agricultural Academy, Izhevsk) (2011) 436 p.

8. B.B. McSpadden, D.R. Fravel, Biological control of plant pathogens: Research, commercialization, and application in the USA, Plant Health Progress (2002) doi:10.1094/PHP-2002-0510-01-RV.

9. J. Hallmann, A. Quadt-Hallmann, W.F. Mahaffee, J. W. Kloepper, Bacterial endophytes in agricultural crops, Can. J. Microbiol., 43, 895-914 (1997)

10. B.A. Dospekhov, Methodology of field experience (with the basics of statistical processing of research results) (Kolos, Moscow, 1985) 416 p. 